\title{
Intracellular pH regulation by Mycobacterium smegmatis and Mycobacterium bovis BCG
}

\author{
Min Rao, Trevor L. Streur, Frank E. Aldwell and Gregory M. Cook \\ Author for correspondence: Gregory M. Cook. Tel: +64 3479 7722. Fax: +6434798540 \\ e-mail: greg.cook@stonebow.otago.ac.nz
}

Department of

Microbiology, Otago

School of Medical Sciences,

University of Otago,

PO Box 56, Dunedin,

New Zealand

\begin{abstract}
Mycobacteria are likely to encounter acidic pH in the environments they inhabit; however intracellular pH homeostasis has not been investigated in these bacteria. In this study, Mycobacterium smegmatis and Mycobacterium bovis [Bacille Calmette-Guérin (BCG)] were used as examples of fast- and slowgrowing mycobacteria, respectively, to study biochemical and physiological responses to acidic $\mathrm{pH}$. $M$. smegmatis and $M$. bovis BCG were able to grow at $\mathrm{pH}$ values of 4.5 and 5.0 , respectively, suggesting the ability to regulate internal pH. Both species of mycobacteria maintained their internal pH between $\mathrm{pH} \mathrm{6.1}$ and 7.2 when exposed to decreasing external pH and the maximum $\Delta \mathrm{pH}$ observed was approximately $2 \cdot 1$ to $2 \cdot 3$ units for both bacteria. The $\Delta \mathrm{pH}$ of $M$. smegmatis at external pH 5.0 was dissipated by protonophores (e.g. carbonyl cyanide $m$-chlorophenylhydrazone), ionophores (e.g. monensin and nigericin) and $N, N^{\prime}$-dicyclohexylcarbodiimide (DCCD), an inhibitor of the proton-translocating $F_{1} F_{0}$-ATPase. These results demonstrate that permeability of the cytoplasmic membrane to protons and proton extrusion by the $F_{1} F_{0}$ ATPase plays a key role in maintaining internal pH near neutral. Correlations between measured internal $\mathrm{pH}$ and cell viability indicated that the lethal internal pH for both strains of mycobacteria was less than pH 6.0. Compounds that decreased internal $\mathrm{pH}$ caused a rapid decrease in cell survival at acidic $\mathrm{pH}$, but not at neutral pH. These data indicate that both strains of mycobacteria exhibit intracellular pH homeostasis and this was crucial for the survival of these bacteria at acidic pH values.
\end{abstract}

Keywords: $\mathrm{pH}$ regulation, mycobacteria, membrane potential, proton ATPase

\section{INTRODUCTION}

Mycobacterium tuberculosis, the principal agent of tuberculosis (TB) in humans causes approximately three million deaths per year and it is estimated that up to one third of the world's population has been exposed to TB. Increased susceptibility of HIV-infected individuals and the emergence of multidrug-resistant strains make TB the leading cause of disease by an infectious agent (Bloom \& Murray, 1992). Effective new TB control and prevention strategies will require additional knowledge of the growth mechanisms of M. tuberculosis and its interaction with the host.

Abbreviations: CCCP, carbonyl cyanide m-chlorophenylhydrazone; $\mathrm{DCCD}, N, N^{\prime}$-dicyclohexylcarbodiimide; $\Delta \mathrm{p}$, protonmotive force; $\Delta \mathrm{pH}$, transmembrane proton gradient expressed as $\mathrm{pH}$ units; $\Delta \Psi$, membrane potential; $\mathrm{TPP}^{+}$, methyl triphenylphosphonium iodide; $\mathrm{Z} \Delta \mathrm{pH}$, transmembrane proton gradient expressed in $\mathrm{mV}$.
Mycobacteria are likely to encounter both acidic and mildly acidic $\mathrm{pH}$ in the environments they inhabit (Sturgill-Koszycki et al., 1994; Oh \& Straubinger, 1996; Iivanainen et al., 1999). For example, acidic conditions ( $\mathrm{pH} 3 \cdot 5-4 \cdot 3)$ often prevail in soil and aquatic habitats where saprophytic mycobacteria are found (Iivanainen et al., 1999). In the host environment, M. tuberculosis has been shown to reside in the phagocytic vacuole of host macrophages where the intraphagosomal $\mathrm{pH}$ has been shown to be mildly acidic $(\mathrm{pH} 6 \cdot 1-$ 6.5) (Sturgill-Koszycki et al., 1994; Oh \& Straubinger, 1996). Reports in the 1960s demonstrated that $M$. tuberculosis $\mathrm{H} 37 \mathrm{Rv}$ had a narrow $\mathrm{pH}$ range for growth between $\mathrm{pH} 6 \cdot 2$ and $7 \cdot 3$ with marked attenuation observed at $\mathrm{pH} 5.0$ and 8.4 (Chapman \& Bernard, 1962). Other species of mycobacteria, for example Mycobacterium fortuitum, Mycobacterium marinum, Mycobacterium scrofulaceum, Mycobacterium avium and Mycobacterium chelonae, grew at $\mathrm{pH} 6.0$ in an 
unrestricted manner indicating that M. tuberculosis was unique among the mycobacteria in its extreme sensitivity to acid (Chapman \& Bernard, 1962). Portaels \& Pattyn (1982) reported that Mycobacterium smegmatis was capable of growth over a wide $\mathrm{pH}$ range with optimum growth observed between $\mathrm{pH} 5 \cdot 0$ and $7 \cdot 4$, and partial growth at $\mathrm{pH} 4 \cdot 6$. A more recent study by O'Brien et al. (1996) has demonstrated that exposure of M. smegmatis to sublethal, adaptive acidic $\mathrm{pH}($ e.g. $\mathrm{pH} 5 \cdot 0$ ) conferred a significant level of protection against subsequent exposure to lethal $\mathrm{pH}$ (e.g. $\mathrm{pH} 3.0$ ) compared to unadapted cells grown at $\mathrm{pH} 7 \cdot 6$, but no mechanism for this acid-tolerant response was provided. In contrast to other micro-organisms that exhibit an acid-tolerant response or acid habituation, the magnitude of protection was only a two- to threefold increase in cell viability for M. smegmatis compared to adapted cells of Salmonella typhimurium which are 100 to 1000 times more resistant to strong acid challenge (e.g. pH 3.3) compared to unadapted cells (Foster \& Hall, 1990).

Due to the paucity of basic information that exists on how mycobacteria cope with acidic $\mathrm{pH}$ and $\mathrm{pH}$ in general, we have studied the effect of external $\mathrm{pH}$ on intracellular $\mathrm{pH}$ homeostasis in M. smegmatis and Mycobacterium bovis BCG. The results reported in this communication demonstrate that both species of mycobacteria adopt intracellular $\mathrm{pH}$ homeostasis and this was essential for survival at acidic $\mathrm{pH}$.

\section{METHODS}

Chemicals and radiochemicals. CCCP (carbonyl cyanide $m$ chlorophenylhydrazone), DCCD (N,N'-dicyclohexylcarbodiimide), monensin, valinomycin and nigericin were obtained from Sigma. [Carboxyl- ${ }^{14} \mathrm{C}$ ]salicylic acid $\left(56 \mathrm{mCi} \mathrm{mmol}^{-1}\right)$ was obtained from ICN Biomedicals. The following radiochemicals were obtained from NEN: $\left[{ }^{3} \mathrm{H}\right]$ methyltriphenylphosphonium iodide $\left(\mathrm{TPP}^{+}\right) \quad\left(30-60 \mathrm{Ci} \mathrm{mmol}^{-1}\right), \quad\left[7^{-14} \mathrm{C}\right]-$ benzoic acid $\left(10-25 \mathrm{mCi} \mathrm{mmol}^{-1}\right), \quad\left[1,2-{ }^{3} \mathrm{H}\right]$ taurine $(5-30$ $\left.\mathrm{Ci} \mathrm{mmol}{ }^{-1}\right)$ and $\left[{ }^{3} \mathrm{H}\right]$ water $\left(25 \mathrm{mCi} \mathrm{g}^{-1}\right)$.

Growth and maintenance. Cultures of M. smegmatis $\mathrm{mc}^{2} 155$ (Snapper et al., 1990) and M. bovis BCG (Pasteur 1173P2) were used in this study. For liquid culture, cells were grown with gentle agitation at $37^{\circ} \mathrm{C}$ in supplemented Middlebrook 7H9 broth (Difco Laboratories) containing sterile Middlebrook ADC enrichment (Becton Dickinson) and 0.05\% Tween 80 (Sigma). For solid medium, supplemented Middlebrook $7 \mathrm{H} 11$ (1.5\% agar) with OADC (Becton Dickinson) and glycerol $(0 \cdot 5 \%, \mathrm{v} / \mathrm{v})$ was used. All cells used as inocula were washed in saline $(0.85 \% \mathrm{NaCl})$. To acidify supplemented and non-supplemented 7H9 medium, the $\mathrm{pH}$ was adjusted with $2 \mathrm{M} \mathrm{HCl}$. Culture optical density was measured with a Beckman DU-64 spectrophotometer at $600 \mathrm{~nm}\left(\mathrm{OD}_{600}\right)$ using culture samples diluted with saline to bring the $\mathrm{OD}_{600}$ to below 0.7 when measured in cells of $1 \mathrm{~cm}$ light path length.

Protonmotive force $(\Delta p)$ measurements. Mid-exponential phase cultures were harvested by centrifugation $(8000 \mathrm{~g}, 15$ min, $10^{\circ} \mathrm{C}$ ) and washed in $100 \mathrm{mM}$ sodium citrate/phosphate buffer $(\mathrm{pH} 7 \cdot 0)$. Cells were resuspended to a final $\mathrm{OD}_{600}$ of $1 \cdot 0$ in a volume of $2 \mathrm{ml}$ (glass tubes). Where the external $\mathrm{pH}$ was varied ( $\mathrm{pH} 4 \cdot 0$ to $7 \cdot 0$ ), initial experiments were carried out using non-supplemented $7 \mathrm{H} 9$ medium, but there was no detectable difference in $\Delta \mathrm{pH}$ values between using this medium and one of the following buffers; $100 \mathrm{mM}$ sodium citrate/ phosphate buffer, $100 \mathrm{mM}$ potassium- and sodium-phosphate buffer at the external $\mathrm{pH}$ being studied. Citrate/phosphate buffer has been used extensively for measuring internal $\mathrm{pH}$ and acid survival in other bacteria (Baronofsky et al., 1984; Terracciano \& Kashket, 1986; McGowan et al., 1998) and this was the buffer routinely used in this study. Cells were energized with $20 \mathrm{mM}$ glucose for $15 \mathrm{~min}$ followed by the addition of $\left[{ }^{3} \mathrm{H}\right] \mathrm{TPP}^{+}\left(5 \mu \mathrm{M}\right.$ final concentration), $\left[7^{-14} \mathrm{C}\right]$ benzoate $(11 \mu \mathrm{M}$, $\left.\mathrm{pK}_{\mathrm{a}} 4 \cdot 2\right)$ or $\left[{ }^{14} \mathrm{C}\right]$ salicylic acid $\left(10 \mu \mathrm{M}, \mathrm{pK}_{\mathrm{a}} 3 \cdot 0\right)$ at $\mathrm{pH}$ values below $5 \cdot 0$. $\left[1,2-{ }^{3} \mathrm{H}\right]$ taurine $(50 \mu \mathrm{M})$ and ${ }^{3} \mathrm{H}_{2} \mathrm{O}(25 \mathrm{mM})$ were used to determine intracellular volume. Taurine has been shown to be non-metabolizable by M. tuberculosis (Zhang et al., 1999) and this was confirmed for the mycobacteria used in this study. After incubation for $10 \mathrm{~min}$ at $37^{\circ} \mathrm{C}$, the cultures were centrifuged through $0 \cdot 35 \mathrm{ml}$ silicon oil (BDH Laboratory Supplies) in $1.5 \mathrm{ml}$ microcentrifuge tubes $(13000 \mathrm{~g}$, $5 \mathrm{~min}$, $22^{\circ} \mathrm{C}$ ) and $20 \mu \mathrm{l}$ samples of supernatant were removed. The tubes and contents were frozen $\left(-20^{\circ} \mathrm{C}\right)$, and cell pellets removed with dog nail clippers. Supernatant and cell pellets were dissolved in scintillation fluid and counted. The silicon oil mix used in this study was a $40 \%$ mixture of phthalic acid bis(2-ethylhexyl ester) and $60 \%$ silicone oil (40\% part mixture of DC200/200 silicone oil and 60\% DC 550). Silicone oils were left overnight at room temperature to equilibrate.

The intracellular volume $\left[3.45 \pm 0.59 \mu \mathrm{l}(\mathrm{mg} \text { protein })^{-1}\right]$ was estimated from the difference between the partitioning of ${ }^{3} \mathrm{H}_{2} \mathrm{O}$ and $\left[{ }^{14} \mathrm{C}\right]$ taurine. The electrical potential across the cell membrane (membrane potential; $\Delta \Psi$ ) was calculated from the uptake of $\left[{ }^{3} \mathrm{H}\right] \mathrm{TPP}^{+}$according to the Nernst relationship. Non-specific $\mathrm{TPP}^{+}$binding was estimated from cells which had been treated with valinomycin and nigericin $(10 \mu \mathrm{M}$ each) for $25 \mathrm{~min}$. These inhibitors have been used previously with M. smegmatis (De Rossi et al., 1998; Choudhuri et al., 1999). The $\Delta \mathrm{pH}$ was determined from the distribution of $\left[{ }^{14} \mathrm{C}\right]-$ benzoate or $\left[{ }^{14} \mathrm{C}\right]$ salicylic acid using the HendersonHasselbalch equation (Reibeling et al., 1975) and $\mathrm{Z} \Delta \mathrm{pH}$ was calculated as $62 \mathrm{mV} \times \Delta \mathrm{pH}$.

Determination of lethal internal $\mathrm{pH}$ for $\boldsymbol{M}$. smegmatis and $\boldsymbol{M}$. bovis BCG. The determination of lethal internal $\mathrm{pH}$ for $M$. smegmatis and M. bovis BCG was as reported by Foster \& Hall (1991). Mycobacteria were grown to the exponential phase $\left(\mathrm{OD}_{600} 0 \cdot 5-1 \cdot 0\right)$ in supplemented $7 \mathrm{H} 9$ broths $(\mathrm{pH} 7 \cdot 0)$ and harvested by centrifugation $\left(8000 \mathrm{~g}, 15 \mathrm{~min}, 10^{\circ} \mathrm{C}\right)$. Cells were resuspended in non-supplemented $7 \mathrm{H} 9$ medium and $20 \mathrm{mM}$ glucose at $\mathrm{pH} 5.0$ or 5.5 . Preliminary experiments indicated that $20 \mathrm{~min}$ exposure to $500 \mu \mathrm{M}$ CCCP prior to the measurement of intracellular $\mathrm{pH}$ was required to reduce the internal $\mathrm{pH}$ from 6.7 to $5 \cdot 5$, but CCCP did not eliminate $\Delta \mathrm{pH}$ completely. An exposure time of $4 \mathrm{~h}$ to $250 \mu \mathrm{M}$ CCCP at $\mathrm{pH} 5.0$ was required to cause a $68 \%$ decline in viability of $M$. smegmatis; this was the time chosen for cell-survival experiments. To reduce the level of CCCP associated with the cells prior to plating, cell suspensions were harvested by centrifugation $\left(13000 \mathrm{~g}, 5 \mathrm{~min}, 22^{\circ} \mathrm{C}\right)$ and washed twice in $1.5 \mathrm{ml}$ sterile $0.9 \% \mathrm{NaCl}$. Cell viability (survival) was determined as the number of bacteria remaining as a percentage of the starting count. All samples were diluted in sterile saline $(\mathrm{pH} 7 \cdot 0)$ and three $100 \mu \mathrm{l}$ volumes of each dilution $\left(10^{-4}-10^{-6}\right.$ ) were spread plated on $7 \mathrm{H} 11$ agar plates in duplicate. Cell viability, as measured by c.f.u., was determined after $2-3 \mathrm{~d}$ for M. smegmatis and 2-3 weeks for $M$. bovis BCG, or after colonies were visible at $37^{\circ} \mathrm{C}$. The minimum detection limit was 100 c.f.u. $\mathrm{ml}^{-1}$. The results are expressed as log percentage 
survival and represent the mean values of two independent experiments.

Measurement of oxygen consumption by washed cell suspensions, and other analyses. For oxygen consumption measurements, cells were harvested from exponentially growing cultures $\left(\mathrm{OD}_{600} \sim 0.5\right)$ by centrifugation $(8000 \mathrm{~g}, 15 \mathrm{~min}$, $10^{\circ} \mathrm{C}$ ), washed in $100 \mathrm{mM}$ sodium citrate/phosphate buffer $(\mathrm{pH} 7 \cdot 0)$ and resuspended in the same buffer to give protein concentrations of $5-10 \mathrm{mg}$ protein $\mathrm{ml}^{-1}$. Respiration rates were measured in a Rank Bros Clark-type oxygen electrode at $37^{\circ} \mathrm{C}$ as described by Carneiro de Melo et al. (1996). Glucose $(20 \mathrm{mM})$ was added as an oxidizable carbon source. The oxygen electrode was calibrated with air-saturated sodium citrate/phosphate buffer $\left(220 \mathrm{nmol}\right.$ dissolved $\mathrm{O}_{2} \mathrm{ml}^{-1}$ at $\left.37^{\circ} \mathrm{C}\right)$. Protein from $\mathrm{NaOH}$-hydrolysed cells $(0 \cdot 2 \mathrm{M} \mathrm{NaOH}$, $100{ }^{\circ} \mathrm{C}, 20 \mathrm{~min}$ ) and cell membranes was assayed by the method of Markwell et al. (1978).

Preparation of bacterial cell membranes and ATPase assays. Cell membranes of $M$. smegmatis were prepared as previously described (Basu et al., 1992). Membrane-bound ATPase activity was determined in triplicate by the colourimetric assay of inorganic phosphate liberated from ATP hydrolysis as described by Kobayashi \& Anraku (1972). The incubation time and concentration of membrane protein was adjusted so that the assay was linear with time and less than $50 \%$ of the ATP hydrolysed. Non-enzymic degradation of ATP under these conditions was less than $10 \%$ of the total phosphate. ATPase activity was expressed as $\mu \mathrm{mol}$ inorganic phosphate liberated $\min ^{-1}$ (mg protein $)^{-1}$ at $37^{\circ} \mathrm{C}$.

\section{RESULTS}

\section{The effect of extracellular $\mathrm{pH}$ on the growth of $M$. smegmatis and $M$. bovis BCG}

M. smegmatis grew rapidly in $7 \mathrm{H} 9$ broth at $\mathrm{pH} 7 \cdot 0$ and the maximum specific growth rate observed was approximately $0.28 \mathrm{~h}^{-1}$ (Fig. 1). When the initial $\mathrm{pH}$ of

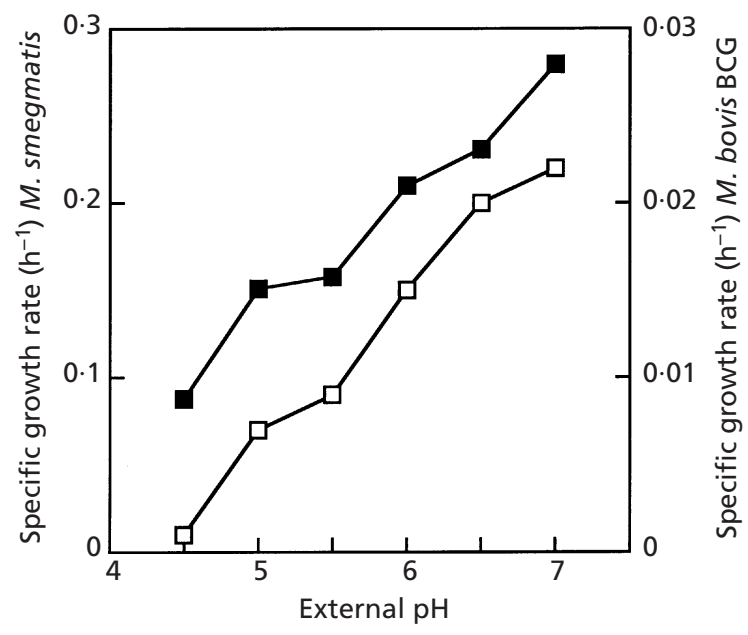

Fig. 1. The effect of extracellular $\mathrm{pH}$ on specific growth rate $\left(\mathrm{h}^{-1}\right)$ of $M$. smegmatis $(\square)$ and $M$. bovis BCG ( $\square$ ) grown in supplemented $7 \mathrm{H} 9$ broth at the $\mathrm{pH}$ indicated. The specific growth rate $\left(\mathrm{h}^{-1}\right)$ was determined in the mid-exponential phase of growth.
$7 \mathrm{H} 9$ broth was adjusted to $\mathrm{pH}$ values in the range $4 \cdot 5$ to $7 \cdot 0$, the growth rate decreased with declining extracellular $\mathrm{pH}$ to approximately $0 \cdot 09 \mathrm{~h}^{-1}$ at $\mathrm{pH} 4 \cdot 5$ (Fig. 1 ). A comparative analysis with $M$. bovis BCG under identical growth conditions revealed a similar pattern of $\mathrm{pH}$ sensitivity (Fig. 1). In these experiments, the final $\mathrm{pH}$ was between 0.2 and 0.5 units higher than the initial $\mathrm{pH}$ value.

\section{Regulation of internal $\mathrm{pH}$ by $M$. smegmatis and M. bovis BCG}

Oxygen consumption measurements were performed to determine the energy status of washed cell suspensions for internal $\mathrm{pH}$ measurements. Non-energized cell suspensions of $M$. smegmatis at $\mathrm{pH} 7 \cdot 0$ consumed

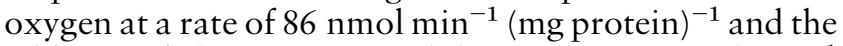
addition of glucose increased the rate to $165 \mathrm{nmol} \mathrm{min}{ }^{-1}$ $(\mathrm{mg} \text { protein })^{-1}$. At $\mathrm{pH} 5 \cdot 0$, the rate of oxygen consumption by non-energized cells was $99 \mathrm{nmol} \mathrm{m^{-1 }}$ (mg protein $)^{-1}$ and this was increased to $126 \mathrm{nmol} \mathrm{m^{-1 }}$ $(\mathrm{mg} \text { protein })^{-1}$ by glucose addition. Non-energized cell suspensions of $M$. bovis BCG at $\mathrm{pH} 7 \cdot 0$ consumed oxygen at a rate of $32 \mathrm{nmol} \mathrm{m^{-1 }}(\mathrm{mg} \text { protein })^{-1}$ and the addition of glucose increased the rate to $42 \mathrm{nmol} \mathrm{\textrm {min } ^ { - 1 }}$ $(\mathrm{mg} \text { protein })^{-1}$. At $\mathrm{pH} 5 \cdot 5$, the rate of oxygen consumption by non-energized cells was $21 \mathrm{nmol} \mathrm{min}^{-1}(\mathrm{mg}$ protein $)^{-1}$ and this was increased to $24 \mathrm{nmol} \mathrm{m^{-1 }}(\mathrm{mg}$ protein) $)^{-1}$ by glucose addition.

The use of radioactive probes to measure the total $\Delta \mathrm{p}$ requires corrections for non-specific binding of probes such as $\mathrm{TPP}^{+}$. Since the cell wall of mycobacteria is unlike that of conventional eubacteria, we first tested the effect of ionophores and protonophores on the growth of these bacteria. The following inhibitors at the concentrations listed completely arrested growth of exponentially growing cells of $\mathrm{M}$. smegmatis at $\mathrm{pH} 7 \cdot 0$ : CCCP, $100 \mu \mathrm{M}$; DCCD, $200 \mu \mathrm{M}$; monensin, $100 \mu \mathrm{M}$; nigericin/valinomycin, $10 \mu \mathrm{M}$ each. At $\mathrm{pH} 5 \cdot 0$, the following concentrations were required to inhibit growth of $M$. smegmatis; CCCP, $50 \mu \mathrm{M}$; DCCD, $300 \mu \mathrm{M}$; monensin, $10 \mu \mathrm{M}$; nigericin/valinomycin, $10 \mu \mathrm{M}$ each. These inhibitors were also effective against $M$. bovis BCG at similar concentrations (data not shown). These results show that the cell wall of $M$. smegmatis and M. bovis BCG did not pose a barrier to these compounds.

The effect of extracellular $\mathrm{pH}$ on intracellular $\mathrm{pH}$ regulation was studied over the $\mathrm{pH}$ range $4 \cdot 0$ to $7 \cdot 0$ (Fig. $2)$. The $\Delta \Psi$ of $M$. smegmatis was approximately -178 $\mathrm{mV}$ at $\mathrm{pH} 7 \cdot 0$ and decreased with declining $\mathrm{pH}$ (Fig. 2a). As the $\Delta \Psi$ decreased, the total $\Delta \mathrm{p}$ remained greater than $-180 \mathrm{mV}$ and there was an increase in the $\mathrm{Z} \Delta \mathrm{pH}$ from $-8 \mathrm{mV}$ at $\mathrm{pH} 7 \cdot 0$ to $-155 \mathrm{mV}$ at $\mathrm{pH} 4 \cdot 0$ (Fig. 2a). These results indicated that $M$. smegmatis was interconverting $\Delta \Psi$ to $\mathrm{Z} \Delta \mathrm{pH}$ to maintain the $\Delta \mathrm{p}$ constant. The internal $\mathrm{pH}$ as a function of the external $\mathrm{pH}$ is shown in Fig. $2 \mathrm{~b}$. The maximum $\Delta \mathrm{pH}(2.3$ units) was observed at $\mathrm{pH} 4.5$. Identical experiments were carried out with $M$. bovis 


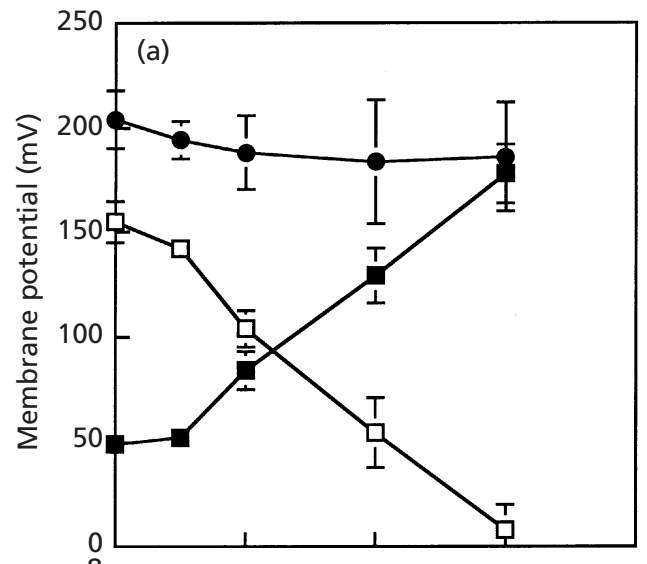

(b)

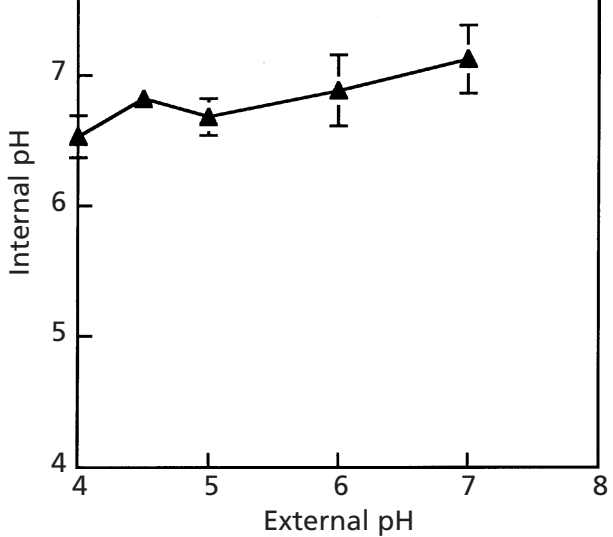

Fig. 2. The effect of extracellular $\mathrm{pH}$ on the individual components of the protonmotive force (a) and internal $\mathrm{pH}$ (b) of $M$. smegmatis. (a) $\Delta \Psi$ ( $\square), \mathrm{Z} \Delta \mathrm{pH}(\square)$ and $\Delta \mathrm{p}$ (0). (b) Internal $\mathrm{pH}(\boldsymbol{\Delta})$ was calculated using the data in (a). Measurements of $\Delta \mathrm{pH}$ and $\Delta \Psi$ and preparation of cell suspensions are described in Methods. The cells (glucoseenergized) were resuspended in sodium citrate/phosphate buffer at the $\mathrm{pH}$ indicated. The $\Delta \mathrm{pH}$ values are the means of three independent experiments and the standard error associated with these determinations is shown.

BCG (Fig. 3). As the external $\mathrm{pH}$ declined, the $\Delta \Psi$ decreased to approximately $-50 \mathrm{mV}$ and the $\mathrm{Z} \Delta \mathrm{pH}$ increased to $-130 \mathrm{mV}$, but the $\Delta \mathrm{p}$ did not remain constant (Fig. 3a). The internal $\mathrm{pH}$ as a function of the external $\mathrm{pH}$ is shown in Fig. $3 \mathrm{~b}$ and the maximal $\Delta \mathrm{pH}$ was $2 \cdot 1$ units observed at an external $\mathrm{pH}$ of $4 \cdot 0$.

\section{Lethal pH for M. smegmatis and M. bovis BCG}

Based on the experiments of Foster \& Hall (1991), one can estimate the lethal internal $\mathrm{pH}$ by adding protonophores, compounds that move protons to equilibrate the internal $\mathrm{pH}$ with the external $\mathrm{pH}$, to cells suspended in medium at $\mathrm{pH} 5 \cdot 0$, an external $\mathrm{pH}$ that is ordinarily not harmful to the cell. Correlations between measured internal $\mathrm{pH}$ and viability will indicate the internal $\mathrm{pH}$ at which viability declines. When increasing concen-
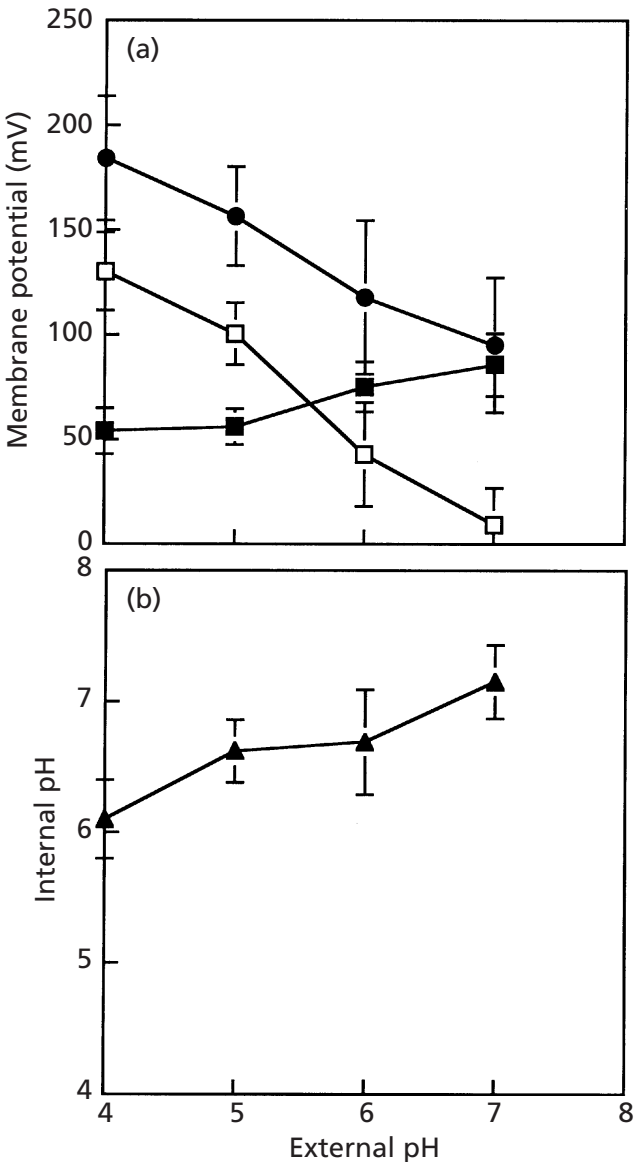

Fig. 3. The effect of extracellular $\mathrm{pH}$ on the individual components of the protonmotive force (a) and internal pH (b) of $M$. bovis BCG. (a) $\Delta \Psi$ ( $\square), Z \Delta \mathrm{pH}(\square)$ and $\Delta \mathrm{p}(\mathbf{O})$. (b) Internal $\mathrm{pH}(\boldsymbol{\Delta})$ was calculated using the data in (a). Measurements of $\Delta \mathrm{pH}$ and $\Delta \Psi$ and preparation of cell suspensions are described in Methods. The cells (glucose-energized) were resuspended in sodium citrate/phosphate buffer at the $\mathrm{pH}$ indicated. The $\Delta \mathrm{pH}$ values are the means of three independent experiments and the standard error associated with these determinations is shown.

trations of CCCP $(0-1 \mathrm{mM})$ were added to $M$. smegmatis cells $\left(\mathrm{OD}_{600} 1 \cdot 0\right)$ resuspended in non-supplemented 7H9 medium containing $20 \mathrm{mM}$ glucose at $\mathrm{pH} 5 \cdot 0$, the internal $\mathrm{pH}$ declined and at $1 \mathrm{mM}$ CCCP the internal $\mathrm{pH}$ was $5 \cdot 1$ (Fig. 4a). The viability of $M$. smegmatis decreased with increasing CCCP concentration and at $500 \mu \mathrm{M}$ CCCP there was a $99 \%$ reduction in cell viability (Fig. $4 \mathrm{~b}$ ). At an external $\mathrm{pH}$ of $7 \cdot 0$, the addition of $500 \mu \mathrm{M}$ CCCP caused only a $20 \%$ reduction in cell viability (data not shown) indicating that the decline in cell viability caused by CCCP was a low-pHinduced lethality.

Identical experiments were performed with M. bovis BCG, but in these experiments the extracellular $\mathrm{pH}$ used was $5 \cdot 5$. The addition of increasing concentrations of CCCP $(0-1 \mathrm{mM})$ to $M$. bovis BCG cells resuspended in non-supplemented 7H9 medium containing $20 \mathrm{mM}$ 


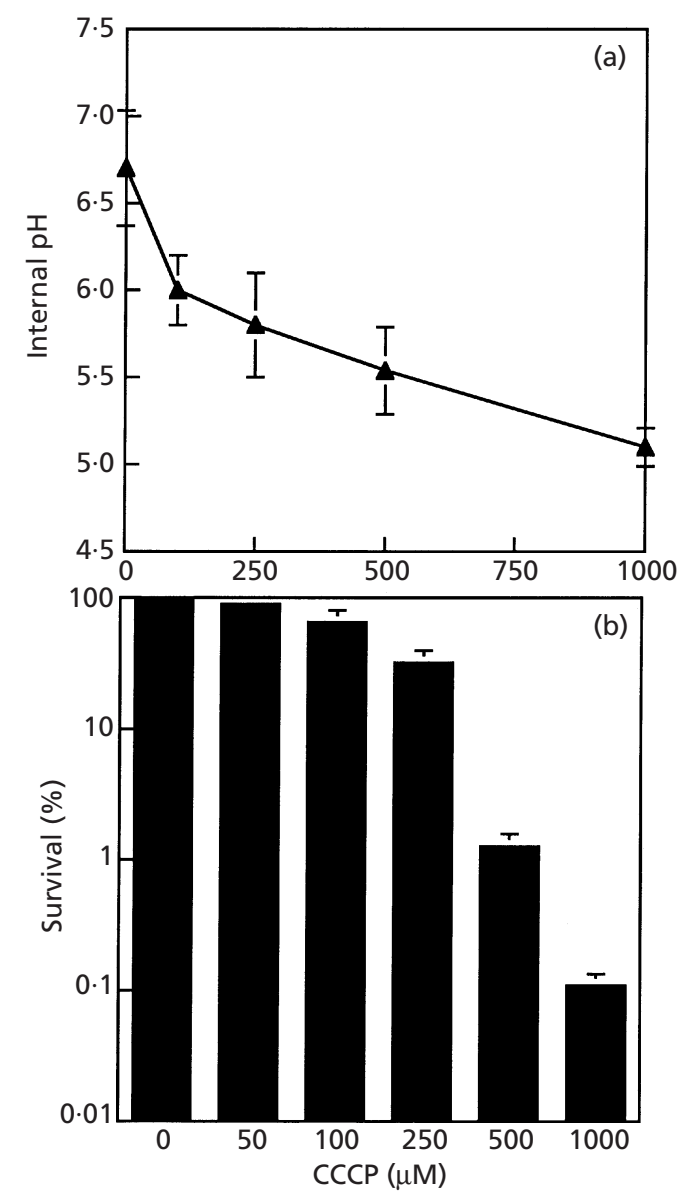

Fig. 4. Effect of increasing concentrations of CCCP on the internal $\mathrm{pH}$ and cell viability of $M$. smegmatis. (a) Glucoseenergized cell suspensions were incubated at $\mathrm{pH} 5.0$ in the presence of CCCP $(0-1 \mathrm{mM})$ for $20 \mathrm{~min}$ and the internal $\mathrm{pH}(\boldsymbol{\Delta})$ was measured as described in Methods. (b) CCCP (0-1 mM) was added to cell suspensions at $\mathrm{pH} 5.0$ in non-supplemented 7H9 medium containing $20 \mathrm{mM}$ glucose and cell viability (c.f.u. $\mathrm{ml}^{-1}$ ) was measured $4 \mathrm{~h}$ after the addition of CCCP. The results are expressed as log percentage survival and represent the mean values of two independent experiments.

glucose at $\mathrm{pH} 5.5$ caused the internal $\mathrm{pH}$ to decline, and at $1 \mathrm{mM}$ CCCP the internal $\mathrm{pH}$ was 5.9 (data not shown). The viability of $M$. bovis BCG decreased with increasing CCCP concentration and at $1 \mathrm{mM}$ CCCP there was a $90 \%$ reduction in cell viability (data not shown). At an external $\mathrm{pH}$ of $7 \cdot 0$, the addition of $1 \mathrm{mM}$ CCCP caused only a $15-20 \%$ reduction in cell viability (data not shown).

\section{Effect of protonophores, ionophores and DCCD on intracellular $\mathrm{pH}$ regulation in $M$. smegmatis}

To gain a better understanding of how mycobacteria regulate their internal $\mathrm{pH}$, experiments were performed with M. smegmatis and known inhibitors of key proteins (e.g. proton-translocating $\mathrm{F}_{1} \mathrm{~F}_{0}-\mathrm{ATPase}$ ) and the generation of ionic gradients (e.g. $\mathrm{H}^{+}, \mathrm{K}^{+}, \mathrm{Na}^{+}$) across the
Table 1. Effect of CCCP, DCCD, monensin and nigericin/valinomycin on the intracellular $\mathrm{pH}$ of M. smegmatis

Internal $\mathrm{pH}$ was measured by $\left[{ }^{14} \mathrm{C}\right]$ benzoic acid equilibration in cells oxidizing glucose. Glucose was added to achieve a final concentration of $20 \mathrm{mM}$. All inhibitors were added $15 \mathrm{~min}$ prior to the addition of $\left[{ }^{14} \mathrm{C}\right]$ benzoic acid. The internal $\mathrm{pH}$ values are the means of two independent experiments and the standard error is shown.

\begin{tabular}{|lcc|}
\hline Treatment & \multicolumn{2}{c|}{ Intracellular pH } \\
\cline { 2 - 3 } & External pH 5.0 & External pH 7·0 \\
\hline Control & $6 \cdot 90 \pm 0 \cdot 11$ & $7 \cdot 38 \pm 0 \cdot 18$ \\
$\quad$ (ethanol treated) & & \\
Valinomycin $(10 \mu \mathrm{M})$ & $6 \cdot 74 \pm 0 \cdot 08$ & $7 \cdot 64 \pm 0 \cdot 15$ \\
Nigericin/valinomycin & $5 \cdot 60 \pm 0 \cdot 12$ & $7 \cdot 28 \pm 0 \cdot 09$ \\
$(10 \mu \mathrm{M}$ each) & & \\
DCCD $(1 \mathrm{mM})$ & $5 \cdot 70 \pm 0 \cdot 21$ & $7 \cdot 60 \pm 0 \cdot 19$ \\
Monensin $(10 \mu \mathrm{M})$ & $5 \cdot 67 \pm 0 \cdot 17$ & $7 \cdot 30 \pm 0 \cdot 13$ \\
CCCP $(500 \mu \mathrm{M})$ & $5 \cdot 54 \pm 0 \cdot 06$ & $7 \cdot 59 \pm 0 \cdot 11$ \\
\hline
\end{tabular}

cell membrane that have been implicated in $\mathrm{pH}$ homeostasis. The addition of either the protonophore CCCP or the ionophore nigericin $\left(\mathrm{K}^{+} / \mathrm{H}^{+}\right.$antiporter $)$in combination with valinomycin $\left(\mathrm{K}^{+}\right.$uniporter), or monensin alone $\left(\mathrm{Na}^{+} / \mathrm{H}^{+}\right.$antiporter) to cells at $\mathrm{pH} 5.0$ almost completely dissipated the $\Delta \mathrm{pH}$ gradient (Table 1). Valinomycin alone had no effect on the $\Delta \mathrm{pH}$ gradient. When DCCD ( $1 \mathrm{mM})$, an inhibitor of the $\mathrm{F}_{1} \mathrm{~F}_{0}$-ATPase, was added to cells at $\mathrm{pH} 5 \cdot 0$, the internal $\mathrm{pH}$ was $5 \cdot 70$ (Table 1). At neutral $\mathrm{pH}$, under all conditions tested, the internal $\mathrm{pH}$ was alkaline with respect to the external $\mathrm{pH}(7 \cdot 28-7 \cdot 60)$ in the presence of the inhibitors used (Table 1).

Growth at low external $\mathrm{pH}$ has been shown to induce the synthesis of the $\mathrm{F}_{1} \mathrm{~F}_{0}$-ATPase in Enterococcus faecalis (Kobayashi et al., 1984, 1986). To determine if a membrane-bound proton-translocating ATPase was being synthesized in M. smegmatis in response to low external $\mathrm{pH}$, cells were grown at $\mathrm{pH} 7 \cdot 0$ and $\mathrm{pH} 5 \cdot 0$, and the amount of ATPase activity determined in purified cell membranes. The cell membranes from cells that were grown at $\mathrm{pH} 7 \cdot 0$ had $4.63 \pm 0.49 \mu \mathrm{mol} \mathrm{min}^{-1}$ $(\mathrm{mg} \text { protein })^{-1}$ ATPase activity. The ATPase activity in cell membranes of cells grown at $\mathrm{pH} 5 \cdot 0$ was $6.48 \pm 0.43 \mu \mathrm{mol} \mathrm{min}^{-1}(\mathrm{mg} \text { protein })^{-1}$. The $\mathrm{pH}$ optimum of the ATPase was approximately $7 \cdot 0$ from both $\mathrm{pH} 5 \cdot 0$ and $7 \cdot 0$ grown cells.

The $\mathrm{F}_{1} \mathrm{~F}_{0}$-ATPase has been shown to be essential for the survival of Escherichia coli at external $\mathrm{pH}$ values below 4.0 (Bearson et al., 1997). Further experiments were conducted to determine the effect of DCCD on the survival of M. smegmatis at both acidic and neutral $\mathrm{pH}$. M. smegmatis cells were incubated in sodium citrate/ phosphate buffer at $\mathrm{pH} 3 \cdot 0,5 \cdot 0$ and $7 \cdot 0$ in the presence 


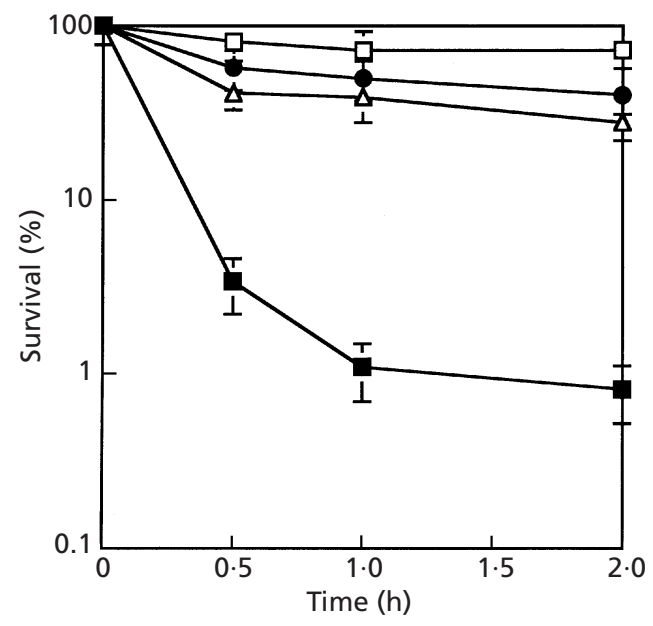

Fig. 5. Effect of DCCD on the survival of exponential-phase $M$. smegmatis at external $\mathrm{pH} 7.0(\triangle), 5.0(\triangle)$ and $3.0(\square)$. M. smegmatis cells (initial inoculum $\sim 10^{8}$ c.f.u. $\mathrm{ml}^{-1}$ ) were incubated for $0-2 \mathrm{~h}$ in sodium citrate/phosphate buffer at $\mathrm{pH} 3.0,5.0$ and 7.0 in the absence or presence of $1 \mathrm{mM} \mathrm{DCCD.} \mathrm{A}$ single line $(\square)$ is shown for the controls (averaged survival values of $\mathrm{pH} 3.0,5.0$ and 7.0 in the absence of DCCD). The results are expressed as log percentage survival and represent the mean values of two independent experiments.

and absence of $1 \mathrm{mM}$ DCCD, a concentration shown to lower the internal $\mathrm{pH}$ at external pH 5.0 (Table 1 ). In the absence of DCCD, M. smegmatis survived at each of the $\mathrm{pH}$ values tested (Fig. 5). The addition of $1 \mathrm{mM}$ DCCD caused a $60 \%$ reduction in viable cell numbers of $M$. smegmatis at $\mathrm{pH} 7.0$ and a $72 \%$ reduction at $\mathrm{pH} 5.0$ (Fig. 5). At an external pH of 3.0, DCCD caused a $99 \%$ decrease in cell viability. These results demonstrate that ATPase activity is required for survival of M. smegmatis at all $\mathrm{pH}$ values tested, but appears to be more essential for survival at low $\mathrm{pH}$ values (e.g. $\mathrm{pH} 3 \cdot 0$ ).

\section{DISCUSSION}

In this study we have carried out a detailed investigation of how mycobacteria cope with low $\mathrm{pH}$ using two model organisms; the fast-growing $M$. smegmatis and the slow-growing $M$. bovis BCG. Our findings indicate that the growth of $M$. smegmatis is inhibited as the external $\mathrm{pH}$ decreases below 4.5, thus supporting previous studies (Chapman \& Bernard, 1962; Portaels \& Pattyn, 1982). M. tuberculosis H37Rv has been reported to have a narrow $\mathrm{pH}$ range for growth between $6 \cdot 2$ and $7 \cdot 3$ with marked attenuation observed at $\mathrm{pH} 5 \cdot 0$ and 8.4 (Chapman \& Bernard, 1962). In this study, growth of $M$. bovis BCG was inhibited at $\mathrm{pH}$ values below $5 \cdot 0$. The results reported here demonstrated that both species of mycobacteria adopt intracellular $\mathrm{pH}$ homeostasis. M. smegmatis and M. bovis BCG maintained their internal $\mathrm{pH}$ in the range $6 \cdot 1-7 \cdot 2$ when examined over the external $\mathrm{pH}$ range of $4 \cdot 0-7 \cdot 0$. At an external $\mathrm{pH}$ of $5 \cdot 0$, the internal $\mathrm{pH}$ of these organisms was $6 \cdot 6-6 \cdot 7$. Zhang et al. (1999) have reported that at an external $\mathrm{pH}$ of $5 \cdot 0$, the internal $\mathrm{pH}$ of $M$. tuberculosis $\mathrm{H} 37 \mathrm{Ra}$ was close to $7 \cdot 0$, supporting the work in this communication and suggesting that $M$. tuberculosis adopts $\mathrm{pH}$ homeostasis.

The maintenance of intracellular $\mathrm{pH}$ near neutrality when faced with decreasing external $\mathrm{pH}$ requires changes in the $\mathrm{Z} \Delta \mathrm{pH}$ that is a component of the $\Delta \mathrm{p}$. One mechanism bacteria employ to modify their $\mathrm{Z} \Delta \mathrm{pH}$ while maintaining $\Delta \mathrm{p}$ constant is to make compensatory changes in $\Delta \Psi$. This may be accomplished by the use of various cation transport systems (Booth, 1985). For example, Enterococcus faecalis and E. coli are able to interconvert $\mathrm{Z} \Delta \mathrm{pH}$ for $\Delta \Psi$ by electrogenic $\mathrm{K}^{+}$transport (Bakker \& Mangerich, 1981; Booth, 1985). Results here indicated that $M$. smegmatis interconverted $\Delta \Psi$ for $\mathrm{Z} \Delta \mathrm{pH}$ to maintain the $\Delta \mathrm{p}$ constant with declining external $\mathrm{pH}$; the $\Delta \mathrm{p}$ values were in good agreement with those published for other respiring neutrophiles (Kashket, 1985). In contrast to M. smegmatis, the $\Delta \mathrm{p}$ for M. bovis BCG varied over the $\mathrm{pH}$ range studied. The differences in $\Delta \mathrm{p}$ were largely reflected in the $\Delta \Psi$ values that varied significantly between the two species. $M$. tuberculosis has been shown to express a multidrug efflux pump, Mmr, that confers resistance to $\mathrm{TPP}^{+}$, ethidium bromide and erythromycin (De Rossi et al., 1998). Importantly, M. smegmatis does not contain the $m m r$ gene and accumulates $\left[{ }^{3} \mathrm{H}\right] \mathrm{TPP}^{+}$with no efflux observed (De Rossi et al., 1998). M. bovis has been shown to contain the $m m r$ gene (De Rossi et al., 1998) and therefore we cannot rule out the operation of a $\mathrm{TPP}^{+}$efflux pump in M. bovis BCG; this may explain the low levels of $\mathrm{TPP}^{+}$accumulation (e.g. low $\Delta \Psi$ ) observed in this species and therefore the large fluctuations in the $\Delta \mathrm{p}$ observed with external $\mathrm{pH}$.

Studies with the protonophore CCCP, used to equilibrate internal $\mathrm{pH}$ with external $\mathrm{pH}$, indicated that the lethal internal $\mathrm{pH}$ for mycobacteria was less than $\mathrm{pH} 6 \cdot 0$ and this was associated with a rapid decrease in cell survival and viability suggesting that in mycobacteria, acid death is related to internal $\mathrm{pH}$ rather than external $\mathrm{pH}$. However, it should be pointed out that at the high concentrations of CCCP used, not only may $\mathrm{H}^{+}$be moved but also other ions (e.g. internal $\mathrm{K}^{+}$) and therefore the effect on viability may not only be due to acidification of the cytoplasm. Foster \& Hall (1991) showed that high concentrations of the protonophore dinitrophenol $(200-400 \mu \mathrm{M})$ were required to collapse the $\Delta \mathrm{pH}$ of $S$. typhimurium. At an external $\mathrm{pH}$ of $4 \cdot 0$, non-growing cells of both mycobacteria had a significant $\Delta \mathrm{p}$ (greater than $-150 \mathrm{mV}$ ) and the internal $\mathrm{pH}$ was greater than $\mathrm{pH} 6 \cdot 0$, but neither species of mycobacteria could grow at this external $\mathrm{pH}$. The reason why these bacteria are unable to grow under conditions where the $\Delta \mathrm{p}$ and internal $\mathrm{pH}$ appear to be favourable for growth is unknown. Perhaps the act of maintaining a high internal $\mathrm{pH}$ under conditions of low growth rate and ATP generation decreases the amount of energy available for growth. The mycobacteria may stop growing at acidic $\mathrm{pH}$ in order to direct energy towards maintenance of their internal $\mathrm{pH}$, which is crucial for their survival. 
Alternatively, there may be a $\mathrm{pH}$-sensitive element (e.g. membrane-bound protein) that is essential for the growth of $M$. smegmatis and M. bovis BCG at acidic $\mathrm{pH}$.

The basic mechanism(s) that mycobacteria use to cope with acidic $\mathrm{pH}$ is not known, but the $\Delta \mathrm{pH}$ gradient of $M$. smegmatis at $\mathrm{pH} 5.0$ was dissipated by the protonophore CCCP and the ionophores monensin and nigericin (Pressman, 1976), indicating that permeability of the cytoplasmic membrane to protons plays a key role in maintaining internal $\mathrm{pH}$ near neutral. Harold et al. (1970) demonstrated that the generation and maintenance of the $\mathrm{pH}$ gradient of Ent. faecalis was energy dependent, and could be prevented by incubation with the $\mathrm{F}_{1} \mathrm{~F}_{0}-\mathrm{ATPase}$ inhibitor DCCD. Furthermore, Ent. faecalis has been shown to increase the amount of $\mathrm{F}_{1} \mathrm{~F}_{0^{-}}$ ATPase twofold when the internal $\mathrm{pH}$ is lowered artificially by gramicidin $\mathrm{D}$ or growth at low $\mathrm{pH}$ (Kobayashi et al., 1984, 1986). The ability of low pH to increase the amount and activity of proton ATPases has also been reported in other bacteria (Nannen \& Hutkins, 1991; Miwa et al., 1997; Amachi et al., 1998; Kullen et al., 1999). In E. coli and Bacillus subtilis, environmental $\mathrm{pH}$ does not influence expression of the atp operon (Santana et al., 1994; Kasimoglu et al., 1996). In this study, DCCD caused a reduction in the $\Delta \mathrm{pH}$ of $M$. smegmatis and there was an increase in the level of membrane-bound ATPase activity in cells that were grown at $\mathrm{pH} 5 \cdot 0$, implying a potential role for this enzyme in intracellular $\mathrm{pH}$ homeostasis. Piddington et al. (2000) have demonstrated a role for $\mathrm{Mg}^{2+}$ in the adaptation of M. tuberculosis to mildly acidic growth conditions, but the role of $\mathrm{Mg}^{2+}$ was unknown. The authors hypothesized that $\mathrm{Mg}^{2+}$ may play a role in the maintenance of neutral $\mathrm{pH}$, perhaps by influencing the $\mathrm{Mg}^{2+}$-dependent proton translocating ATP synthase. Inspection of the $M$. tuberculosis genome sequence reveals homologues of ATP synthase genes (e.g. atpBFEADHCG) (Cole et al., 1998).

Datta \& Benjamin (1997) have demonstrated that DCCD at $1 \mathrm{mM}$ inhibits the survival of Listeria monocytogenes at $\mathrm{pH} 3.0$ but had no effect on the survival of L. monocytogenes at $\mathrm{pH} 7 \cdot 3$, indicating that the effect of DCCD was due to low-pH-induced lethality. Our results demonstrated that M. smegmatis exhibited a striking sensitivity towards DCCD at acidic $\mathrm{pH}$, suggesting that the ATPase may be more essential for survival at acidic pH. E. coli mutants defective in the $\mathrm{F}_{1} \mathrm{~F}_{0}$-ATPase (e.g. atp:: $\operatorname{Tn} 10$ or $\Delta a t p)$ are extremely acid sensitive, but only to external $\mathrm{pH}$ values below 4.0. To test the hypothesis that the ATPase is essential for survival of $M$. smegmatis at low $\mathrm{pH}$ values and rule out potential nonspecific effects of DCCD, further work is required using atp mutants of M. smegmatis.

In conclusion, our data demonstrate that both species of mycobacteria studied here adopt intracellular $\mathrm{pH}$ homeostasis to maintain their internal $\mathrm{pH}$ near neutral at acidic $\mathrm{pH}$. The permeability of the membrane to protons and the activity of the membrane-bound proton
$\mathrm{F}_{1} \mathrm{~F}_{0}$-ATPase play important roles in this process. Current studies are aimed at determining the molecular responses of mycobacteria to $\mathrm{pH}$ stress.

\section{ACKNOWLEDGEMENTS}

This work was funded by a New Zealand Lottery Health Grant. We thank Helen Billman-Jacobe and Dr Geoff deLisle for supplying bacterial strains, and John Foster, Fernanda da Silva Tatley and Theresa Wilson for helpful discussions.

\section{REFERENCES}

Amachi, S., Ishikawa, K., Toyoda, S., Kagawa, Y., Yokota, A. \& Tomita, F. (1998). Characterization of a mutant of Lactococcus lactis with reduced membrane-bound ATPase activity under acidic conditions. Biosci Biotechnol Biochem 62, 1574-1580.

Bakker, E. P. \& Mangerich, W. E. (1981). Interconversion of components of the bacterial proton motive force by electrogenic potassium transport. J Bacteriol 147, 820-826.

Baronofsky, J. J., Schreurs, W. J. A. \& Kashket, E. R. (1984). Uncoupling by acetic acid limits growth of and acetogenesis by Clostridium thermoaceticum. Appl Environ Microbiol 48, 1134-1139.

Basu, J., Chattopadhyay, R., Kundu, M. \& Chakrabarti, P. (1992). Purification and partial characterization of a penicillin-binding protein from Mycobacterium smegmatis. J Bacteriol 174, 4829-4832.

Bearson, S., Bearson, B. \& Foster, J. W. (1997). Acid stress responses in enterobacteria. FEMS Microbiol Lett 147, 173-180.

Bloom, B. R. \& Murray, C. J. L. (1992). Tuberculosis : commentary on a re-emergent killer. Science 257, 1055-1064.

Booth, I. R. (1985). Regulation of cytoplasmic pH. Microbiol Rev 49, 359-378.

Carneiro de Melo, A. M. S., Cook, G. M., Poole, R. K. \& Miles, R. J. (1996). Nisin stimulates oxygen consumption by Staphylococcus aureus and Escherichia coli. Appl Environ Microbiol 62, 1831-1834.

Chapman, J. S. \& Bernard, J. S. (1962). The tolerances of unclassified mycobacteria. Am Rev Respir Dis 86, 582-583.

Choudhuri, B. S., Sen, S. \& Chakrabarti, P. (1999). Isoniazid accumulation in Mycobacterium smegmatis is modulated by proton motive force-driven and ATP-dependent extrusion systems. Biochem Biophys Res Commun 256, 682-684.

Cole, S. T., Brosch, R., Parkhill, J. \& 39 other authors (1998). Deciphering the biology of Mycobacterium tuberculosis from the complete genome sequence. Nature 393, 537-544.

Datta, A. R. \& Benjamin, M. M. (1997). Factors controlling acid tolerance of Listeria monocytogenes: effects of nisin and other ionophores. Appl Environ Microbiol 63, 4123-4126.

De Rossi, E., Branzoni, M., Cantoni, R., Milano, A., Riccardi, G. \& Ciferri, O. (1998). $m m r$, a Mycobacterium tuberculosis gene conferring resistance to small cationic dyes and inhibitors. $J$ Bacteriol 180, 6068-6071.

Foster, J. W. \& Hall, H. K. (1990). Adaptive acidification tolerance response of Salmonella typhimurium. J Bacteriol 172, 771-778.

Foster, J. W. \& Hall, H. K. (1991). Inducible $\mathrm{pH}$ homeostasis and the acid tolerance response of Salmonella typhimurium. J Bacteriol 173, 5129-5135.

Harold, F. M., Pavlasova, E. \& Baarda, J. R. (1970). A transmembrane $\mathrm{pH}$ gradient in Streptococcus faecalis: origin, and 
dissipation by proton conductors and $\mathrm{N}, \mathrm{N}^{\prime}$-dicyclohexylcarbodiimide. Biochim Biophys Acta 196, 235-244.

livanainen, E., Martikainen, P. J., Vaananen, P. \& Katila, M. L. (1999). Environmental factors affecting the occurrence of mycobacteria in brook sediments. J Appl Microbiol 86, 673-681.

Kashket, E. R. (1985). The proton motive force in bacteria: a critical assessment of methods. Annu Rev Microbiol 39, 219-242.

Kasimoglu, E., Park, S. J., Malek, J., Tseng, C. P. \& Gunsalus, R. P. (1996). Transcriptional regulation of the proton-translocating ATPase (atpIBEFHAGDC) operon of Escherichia coli: control by cell growth rate. J Bacteriol 178, 5563-5567.

Kobayashi, H. \& Anraku, Y. (1972). Membrane-bound adenosine triphosphatase of Escherichia coli. J Biochem 71, 387-399.

Kobayashi, H., Suzuki, T., Kinoshita, N. \& Unemoto, T. (1984). Amplification of the Streptococcus faecalis proton-translocating ATPase by a decrease in cytoplasmic pH. J Bacteriol 158, 1157-1160.

Kobayashi, H., Suzuki, T. \& Unemoto, T. (1986). Streptococcal cytoplasmic $\mathrm{pH}$ is regulated by changes in amount and activity of a proton-translocating ATPase. J Biol Chem 261, 627-630.

Kullen, M. J., Klaenhammer, T. R., Brady, L. J., O'Sullivan, D. J., Amann, M. M., O'Shaughnessy, M. J. \& Busta, F. F. (1999). Identification of the $\mathrm{pH}$-inducible, proton-translocating $\mathrm{F}_{1} \mathrm{~F}_{0^{-}}$ ATPase (atpBEFHAGDC) operon of Lactobacillus acidophilus by differential display: gene structure, cloning and characterization. Mol Microbiol 33, 1152-1161.

McGowan, C. C., Necheva, A., Thompson, S. A., Cover, T. L. \& Blaser, M. J. (1998). Acid-induced expression of an LPS-associated gene in Helicobacter pylori. Mol Microbiol 30, 19-31.

Markwell, M. A., Haas, S. M., Bieber, L. L. \& Tolbert, N. E. (1978). A modification of the Lowry procedure to simplify protein determination in membrane and lipoprotein samples. Anal Biochem 87, 206-210.

Miwa, T., Esaki, H., Umemori, J. \& Hino, T. (1997). Activity of $\mathrm{H}\left({ }^{+}\right)$-ATPase in ruminal bacteria with special reference to acid tolerance. Appl Environ Microbiol 63, 2155-2158.

Nannen, N. L. \& Hutkins, R. W. (1991). Proton-translocating adenosine triphosphatase activity in lactic acid bacteria. J Dairy Sci 74, 747-751.

O'Brien, L. M., Gordon, S. V., Roberts, I. S. \& Andrew, P. W. (1996). Response of Mycobacterium smegmatis to acid stress. FEMS Microbiol Lett 139, 11-17.
Oh, Y. K. \& Straubinger, R. M. (1996). Intracellular fate of Mycobacterium avium: use of dual-label spectrofluorometry to investigate the influence of bacterial viability and opsonization on phagosomal $\mathrm{pH}$ and phagosome-lysosome interaction. Infect Immun 64, 319-325.

Piddington, D. L., Kashkouli, A. \& Buchmeier, N. A. (2000). Growth of Mycobacterium tuberculosis in a defined medium is very restricted by acid $\mathrm{pH}$ and $\mathrm{Mg}\left({ }^{2+}\right)$ levels. Infect Immun 68, $4518-4522$.

Portaels, F. \& Pattyn, S. R. (1982). Growth of mycobacteria in relation to the $\mathrm{pH}$ of the medium. Ann Inst Pasteur 133B, 213-221.

Pressman, B. C. (1976). Biological applications of ionophores. Annu Rev Biochem 45, 501-530.

Reibeling, V., Thauer, R. K. \& Jungermann, K. (1975). The internalalkaline $\mathrm{pH}$ gradient, sensitive to uncoupler at ATPase inhibitor, in growing Clostridium pasteurianum. Eur J Biochem 55, 445-453.

Santana, M., lonescu, M. S., Vertes, A., Longin, R., Kunst, F., Danchin, A. \& Glaser, P. (1994). Bacillus subtilis $\mathrm{F}_{0} \mathrm{~F}_{1}$ ATPase: DNA sequence of the atp operon and characterization of atp mutants. J Bacteriol 176, 6802-6811.

Snapper, S. B., Melton, R. E., Mustafa, S., Kieser, T. \& Jacobs, W. R., Jr (1990). Isolation and characterization of efficient plasmid transformation mutants of Mycobacterium smegmatis. Mol Microbiol 4, 1911-1919.

Sturgill-Koszycki, S., Schlesinger, P. H., Chakraborty, P. \& 7 other authors (1994). Lack of acidification in Mycobacterium phagosomes produced by exclusion of the vesicular proton-ATPase. Science 263, 678-681.

Terracciano, J. S. \& Kashket, E. R. (1986). Intracellular conditions required for initiation of solvent production by Clostridium acetobutylicum. Appl Environ Microbiol 52, 86-91.

Zhang, Y., Scorpio, A., Nikaido, H. \& Sun, Z. (1999). Role of acid $\mathrm{pH}$ and deficient efflux of pyrazinoic acid in unique susceptibility of Mycobacterium tuberculosis to pyrazinamide. J Bacteriol 181, 2044-2049.

Received 20 September 2000; revised 27 November 2000; accepted 22 December 2000. 